\title{
Tretinoin Tocoferil
}

National Cancer Institute

\section{Source}

National Cancer Institute. Tretinoin Tocoferil. NCI Thesaurus. Code C66628.

An alpha-tocopherol ester of all trans-retinoic acid (AT RA or tretinoin), with skin healing, differentiation inducing and anti-leukemia activities. By stimulating the formation of tissue granulation and wound healing, tretinoin tocoferil promotes the healing of skin ulcers. In addition, this agent induces the granulocytic differentiation of human leukemia cells and inhibits cellular proliferation. Tretinoin tocoferil does not induce teratogenesis and is less toxic than ATRA. 